\title{
The Challenges of Globalization to Africa: Theoretical Reflections and Practical Assessments
}

\author{
Tewodros Kassie, Yemiamrew Jorgie
}

\begin{abstract}
The political economy of Africa has been marginalized for long since the commencement of relations with the outside world, despite the much rosy explanations that western institutions provide to justify their policy prescriptions. And it is plausible that it will remain indefinitely. Guided by a post-modernist pragmatic knowledge claim, this study follows a qualitative interpretative methodology to make an analytical explanatory inquiry on the nexus between the process of globalization, the opportunities and challenges of it on the political economy of African states, and the strategies that have been adopted hitherto. As it strives to make sense of the convergence and divergence of Western countries and their institutions policy prescription and the policy tenets that most African states are applauding much as an alternative to it against the political economy nature, dynamics, and patterns of African countries, ample data from primary and secondary sources are collected. This paper analyzed, using the ethos of qualitative method data collections and analysis, data from secondary sources such as policy documents, official reports, academic journals, periodicals, proceedings, books, newspapers, and magazines. The overall effect of globalization on the political economy of most African states have been negative. This does not deny the disproportionate share of the benefits from it for some countries due to their comparative advantage or the trickle-down effects. The aspect of development in theories either in capturing the evolving dynamics or in providing policy prescription to include Africa into the process of global political economy disadvantaged Africa. There has been much disregard, save for the legacies of former relationships, to incorporate extant political economy nature of African states in the theorization as much in policy prescriptions African states have been advised to adopt to maximize benefits from the process of globalization. The study also finds that neither African experience of using emerging alternative policies and strategies such as intra-Africa regional integration frameworks; development cooperation frameworks with Asia's emerging economies; and alternative development cooperation frameworks with the USA and EU have provided sound returns for African states. Nor the urgency most Africa's felt to strengthen their capacity to avoid the effects of and to extract available benefits from the process of globalization by playing the established Washington consensus against the emerging Beijing consensus and south-south cooperation frameworks have been strong enough to provide the expected benefits. Indeed, limited progress have been observed in African regional cooperation and integration schemes in some limited areas; though what have been achieved is far lagging behind what could have been accomplished. Lastly, developments since 2001 have provided Africa both opportunities and challenges. Besides the BWIs multilateral institutions initiatives aimed at
\end{abstract}

Tewodros Kassie, Department of Political Science and International Relations, Wollo University, College of Social Science and Humanities, Dessie, Ethiopia

Yemiamrew Jorgie, Department of Social Anthropology, Wollo University, College of Social Science and Humanities, Dessie, Ethiopia establishing bilateral relations with Africa prevailed-USA's AGOA and EU's-EBA since 2001. Of the three dominant theories of political economy, Realism and Marxism do have much explanatory currency than liberalism, in this regard. The liberal explanation that globalization would benefit the political economy of Africa is nothing but unrealistic normative wishes of positive sum game politics and economic relations of mutual benefit. Moreover, the adoption of values, cultures and practices of liberal democracy can serve as the best panacea for all existing socio-political and cultural drawbacks hampering the birth of the preconditions for the political economy transformation that it claims would be achieved.

Index Terms - Globalization, Africa, Political Economy, Neoliberalism, Washington consensus, South-South Cooperation, Regional Integration.

\section{INTRODUCTION}

Much has been written about globalization and its relation with the African continent. Scholarly works on the contents, perspectives, concepts, and issues the process of globalization; and the pros and cons of globalization on developing countries, particularly on African countries have been topical. There are various perspectives and theorizations, that are sometimes complimentary or/and diametrically opposite to each other, on the nature, patterns, forces/actors, dimensions/aspects and impacts of globalization on the international relations of states in general and on Africa in particular. More importantly, each perspective has its ontological assumptions, epistemological foundations and methodological orientations in understanding and explaining African states with all aspects of the people (political, economic, cultural and civilizational) with the peoples of the international community hitherto. For long western developed countries and their institutions, or better Bretton woods institutions (BWIs), have been the primary actors often mentioned both positively and negatively. At least the two decades since the end of the Cold war had been the decades of Western hegemony or better the uncontested unilateral global hegemony years of US. There are multiple discourses about the process of globalization and its impact on the nature of African states. Particularly, the end of the Cold War Era has led to the proliferation of widely held views on the emergence of the New World Order: it has dictated the ascendancy of the West and the demise and disintegration of the East/the socialist block. Arguably, some viewed globalization as a historical process that is creating the universalization of the world culture, politics, and economy. Seen from such perspective, globalization has become synonymous with strengthening global interdependence, witnessing the hegemonic rise of global capitalism, and 
advancing the emergence of a global mass culture (Claude Ake; 1995; 22-3 as cited in Nabudere, 2000; 11-2).

The cold war has had significant consequences on the political order of many African countries. During its height in the 1960's and 1970's, it witnessed the emergence of authoritarian regimes in the form of one-party or military regimes. This was largely a result of the support of either US or USSR- the then hegemonies-to keep African countries in their respective camps and spheres of influence. According to Christopher Clapham $(1993 ; 428)$ the post independent states of Africa and governments were such that:

The non-democratic structure of ...domestic government was reinforced by the international system through direct political and military means, as well as through the operation of the global political economy....the very feebleness the domestic state structure made ...governments to cling to 'juridical statehood' to compensate for the inadequacy of real or 'empirical' statehood(428).

In any event, both one party and military regimes inhibited the emergence of democratic governance and developmentally oriented regimes in Africa. However, this should not meant to dismiss the developmental undertakings of some African governments as some of the first generation governments were developmental in intention and policy direction (see Claude Ake, 1996; MKandawire, 2001). On balance, the effect of the cold war on the political economy of African countries was a blessing in disguise and mixed.

When the cold war ended in 1990, both the U.S. and USSR seemed to lose, if not completely disengaged at all, interest in Africa, leaving their former allies in Africa (Drame, 1996; 207; Clapham, 1993; 432). This has in turn entailed an increase in the number of so called failed states in Africa during the last two decades; and in effect "have ceding the way to the pretensions of rival warlords over devastated economies...[and] Ethnic conflicts, mismanagement and economic crisis threatened the foundation of the other state" (Van De Walle, 1996; 233). The end of the cold war also ended of the previous trends of authoritarian states in getting and having wide options to get assistance because the cold war was conducive enough to offer support from either of the two super powers any kind of leverage that had enabled authoritarian states to stay in power (Clapham, 1993; 428; Wiseman, 1993; 441-443; Rijnierse, 1993; 649).

In effect, Westerns' growing disengagement from Africa and thereof the decline in the strategic importance of Africa has, in turn, substantially reduced the international negotiating power of African countries and with these new world order "a new sets of international rules.... [Prevailed] and has "limited the options for international manoeuvring by African states" (Drame, 1996; 207; Clapham, 1996; 164-5). Africa, in deed, appeared to manifestly face the post cold war 'Pandora's box' global political economy order then opened, and was advised by the "leaders of global meliorism and local elites" (Chomsky,1997;17) to follow the post cold war order as there was no choice but to follow the bandwagon. What has prevailed in the post cold war era is the ascendance of market capitalism and liberal democracy of the developed western states into the political economy claims of the African states through the Bretton Woods Institutions such as World Bank and the IMF with the structural adjustment program (Drame, 1996; 207).

Hence, taking this background into account globalization could be defined as the process of the intensification of economic, political, social and cultural relations across international boundaries. This is evident from its "push of free-market economics, liberal democracy, good governance, and environmental sustainability among other holistic values for the people of the member states" (Rugumamu, 2001; 2; Akindele, Gidado, and Olapo, 2002; 2). It is principally aimed at the transcendental homogenization of political and socio-economic relations across the globe by "increasing breakdown of trade barriers and the increasing integration of World market" (Fafowora, 1998:5).

The determination to follow an independent development-oriented policy direction of African states has been highly compromised to the political economy ideals of the developed western countries. Nor their freedom to adapt policies that may suit their developmental imperatives were unaffected. The structural constraints have then become so complex and hideous that African countries have to willy-nilly adopted the principles and rules of free market economy than even a benign or a rigid stance in favor of keeping or maintaining a protectionist measure. Leaving the yet unsettled debates among experts of various fields about whether the end of cold war is the confirmation of the ascendancy of the politico-economic ideals of the western world, a "New World Order" was inaugurated in 1991. Africa has no choice to have its own independent path as separation from the global power politics is difficult for the highly dependent African states (Rugumamu, 2001; 2; Drame, 1996; 207).

Thus, globalization has emerged as new process acting against the modus operandi and the modus vivendi of the cold war period and with the subsequent erosion of the above elements from the political economy of Africa. Then globalization came to comprise politically, economically and socially inter-connected elements: the expansion of markets; challenges to the state and institutions; and the rise of new social and political movements' (Woods, 2000; 2-5).

From economic point of view, globalization refers to the increasing integration of global markets, money, finance and technology, fueled by increasingly liberalized macroeconomic policy frameworks. It comprises of technological change that in effect have permitted the establishment of transnational networks in production, trade, and finance. More importantly, unlike earlier historical periods, along with the ascendancy of economic globalization MNCs have become a potent actor even having a power worth comparable to the power of those developed states. The rapid progress in the advancement of the communication and internet technology has been the outcome of economic globalization that in turn has been since then another vital agent of the system per se. Internet technology has been 
boosting efficiency and enhancing market integration both domestically and internationally.

The political aspect of globalization, on the other hand, refers to the transformation of global politics. Globalization has led to a new "global politics characterized by a global political order in which states' has become borderless" (Held, et al, 1999; 49) and there upon it is "principally aimed at the universal homogenization of ideas, cultures, values and even life styles as well as, at the de-territorialisation and villagization of the world"(Ohiorhenuan,1998: 6). In the new interconnected global political order, the political doctrines of liberalism have appeared as the dominant global system with down fall of socialism and the end of cold war (Friedman, 2001; 51).

Yet, even if it is argued that globalization has brought about economic growth, democratic governance and liberal tolerance in the western industrialized countries, though not for all, it has also produced a different political order in most African states. As weak African governments try to deal with "increasing economic inequality and political, religious, and tribal backlashes to globalization mentioned above, the result in many cases is a further weakening of the state and democracy, and a heightening of turmoil, and poverty" (Hurrell and Ngaire,1995;447-456). The aim of this paper therefore is to make sense of the dynamism in African political economy in the face of globalization.

It goes without noting that globalization have been a complex historical process in its entirety. More so baffling have been the international relations and political economy of African countries with the forces and actors of globalization. This pieces of article seeks to uncover the political economy trends of African countries in juxtaposition with the process of globalization. Particularly, it aims to analyze globalization and its optimisms to Africa against the backdrop of arguments held by the pro-globalist forces and the concomitant policy prescriptions since the introduction of the Structural Adjustment Programme (SAPs) in late 1980s. Indeed, the integration of African countries political economy with the global political economy on a fragile grounds due to the legacies of colonialism and neocolonialism have been a historical and structural bottleneck. The haste to view globalization as benign, implicitly or explicitly, that developing countries exploit to improve their domestic economic deficit and incapacity have rather been a wishful thinking. Despite the seemingly much prospect that many aspires to see out of the globalization process for Africa by both outsiders and insiders, the effects of past legacies upon the current internal constraining developments and the continuity of past historical structure in a changing present have been apparent. Not so much positive benefits have globalization been providing Africa. In this regard, this paper underscores the importance of identifying how the fragile political economy of African countries have been playing out against the globalization process. Notwithstanding to the limited and disproportionate positive benefits of globalization for some African countries, more often to those rich in natural resources, this paper will identify the much bleak/gloomy prospects of globalization. This, however, should not mistakenly be seen as a blind dismissal of any positive returns from western developed countries and institutions. Rather, this study endeavors to assess the policies and strategies African countries have recently been adopting as a counter to the challenges of western based and driven process of globalization.

\section{Methodological Considerations and Theoretical Perspectives}

\section{A. Methodological Considerations}

The study is basically a qualitatively exploratory and descriptive in its design. Qualitative data gathered from secondary sources such as policy documents, official reports of states \& international institutions, academic journals, periodicals \& proceedings, books, newspapers \& magazines, and etcetera, were analyzed using ethos of qualitative data analysis.

\section{B. Theoretical and Conceptual Considerations \\ Theoretical Perspectives on Globalization}

The evolving economic interdependence of the world on one hand, and the continuing compartmentalization of the global political economy comprising sovereign states on the other hand is a discourse most often addressed by the discipline of political economy. Notwithstanding the dynamics in the global political economy and the changes and continuities of development practices of countries, there are three dominant ideologies/theories that give service in explaining the intricacies therein. Liberalism, Economic Nationalism, and Marxism are the most often cited three dominant contrasting ideologies with competing assumptions over the political economy of development of nation-states, the tenets of the global political economy, the relationship between economic and political change and the nexus therefrom, and the relations and significance of the international political economy for the political economy of states (Gilpin, 1987:14 \& 24).

\section{Liberal Economists}

It is in general a doctrine and set of "principles for organizing and managing a market economy in order to achieve maximum efficiency, economic growth and individual welfare" (Gilpin; 1987:26). It assumes that politics (i.e. the state) and economics (i.e. the market) exist in separate spheres (Martell, 2000; 6). They argue that the "markets- in the interests of efficiency, growth, and consumer choice- should be free from political interference" (Gilpin, 1987:26); given that government intervention in economic and social life is always misguided and usually counterproductive" (Mkandawire, 2001:291; Heywood, 1994:9).

For liberal economists the defining features of capitalist market economic system are the "private ownership of the means of production, the existence of free or wage labor, the profit motive, and the drive to amass capital" (Gilpin, 1987:15). They view globalization as the international flows of trade, capital and productive technologies based on the "... international division of labor... on the principle of comparative advantage cause markets to rise spontaneously and leads to mutual gains among states; thus the consequent 
economic growth will be a basis for peace and cooperation in the competitive and anarchical state system and thereby fostering harmony among states" (Ibid; 12).

\section{Marxists}

Marxism holds that economics derives politics. Political conflicts arise from struggles among classes over the distribution of wealth. Of course, Marxism has developed as critique of market capitalism (Gilpin, 1987:26). Marxist conceptions of political economy are a critique on the liberal's capitalism economic doctrine. As a result, most Marxist literatures comprises of such fundamental elements condemning capitalism as a system of class oppression and exploitation, social disequilibria and looking forward to its inevitable overthrow in a proletariat revolution, out of which socialism and later, communism would arise (Heywood, 1994:10). Thus; Marxist political thought, has a significant impact upon the socialist political economy doctrine, which represents a major alternative to the economic liberalist theory as the dominant strands of western political economic system.

\section{E. Nationalist Perspectives}

Historically, economic nationalism has undergone various changes for many centuries. It has been called by various labels such as mercantilism, statism, protectionism, and recently new protectionism (Gilpin, 1987:31; Ake, 1976:1). They referred to as mercantilism, assume and advocate the primacy of politics over economics as parts of the "doctrine of state-building". It asserts that the market should be subordinate to the pursuit of state interests. For economic nationalists, the state (political factors) should determine economic relations (Gilpin, 1987:26; Chomsky, 1997; 2).

Thus, they focus on national self-sufficient rather than economic interdependence as states' primary objectives. As such, they reject free trade based on the need to protect infant industries and their economies not to be affected due to competition with advanced industries and economies of developed states (Gilpin, 2001:200-201). Their economic system model has incorporated elements both from market capitalism and socialist economic perspective that is a mixed economy system.

In relation to globalization, unlike the liberalist view, nationalists and Marxist largely share the common idea that "trade is merely another arena for international competition, because economic interdependence increases the insecurity of states and their vulnerability to external economic and political forces" (Gilpin, 1997; 56). In addition, they had a common conviction that "international interdependence is not only a cause of conflict and insecurity, but it also creates dependency relations among states. Because interdependence is never symmetrical, trade becomes a source for increasing the political power of the strong over the weak. Therefore, [they] advocate policies of economic autarky" (ibid; 56-57).

\section{RESULTS AND DISCUSSIONS}

\section{A. The Dynamics of the Political Economy of Africa in the face of Globalization}

There are various views on what prospects and opportunities would globalization offer to Africa and any third world state. Cognizant of the aforementioned section, the process of globalization which has currently come to the fore of international political economic order through the dictation of neo liberal market capitalism were perceived to bring about significant political and economic transformation and in turn would improve the wellbeing of African societies.

Yet, reiterating the ideologically based positive benefits of the process of globalization without serious scrutinization and trying to seek solutions to the continued marginalization and exploitative nature of globalization to most developing countries needs to be uncovered afresh always.

In fact, it is vital to examine the effects of policies and practices that the forces of economic globalization are adapting by their institutions and to continually analyse political economy dynamics of Africa in general and some states that are affected significantly. In this regard, these optimisms held about some of the benefits of globalization to the political economy of Africa as prescribed by the SAPs by the dominant forces of the globalization process is assessed on the basis of economic and political aspects separately below.

\section{1) Economic Aspects}

In the 1980s and 1990s, almost every developing country including African states were moving, at their own pace, toward the establishment of a market economy at the order of the WB, which kept advocating "market friendly" economic policies as preconditions for loans (Mkandawire, 2005;157; Mujaju, 2000;37). The policies which African states were normally obliged to accept in exchange for loan were varied as of their rationales. First, "expanded opportunities for trade and the gain driving from trade are the most enticing argument for embracing globalization"(Mkandawire, $2005 ; 156)$ based on the belief that "if Africa is to reverse its unfavorable export trend it must adopt trade liberalization ...that enhance African exporter to capitalize on opportunities in foreign market" (Yeats, 1997; 24).

Moreover, financial liberalization was recommended based on the thesis that "financial repression which include control of interest rate and credit rationing by the state will discourage saving" (Mkandawire, 2005; 157). Needless to mention, for effective and efficient organizations, privatization encompassing opening activities previously controlled by the state as well as privatization of State Corporation was adopted. According to Clapham (1996; 172) the underlying ideological assumption is the association between the most problems of the African economies with the state; hence, the reduction of the state is beneficial in itself. This is presumed to lead to "the glory of the free market as the cure for all the ills of neocolonialism" (Nabudere, 2000; 36). Accordingly, through the policy prescriptions of the international financial institutions, African states have accepted economic policy reforms so as to extract benefits 
from the newly emerged political economic order and there upon to strengthen their integration into the global capitalist market.

On the basis on these, African states take foreign financing besides noninflationary domestic financing to limit their budget deficit. Moreover, the containment of employment in the public sector, liberalization of labor, money and capital market, and the maintenance of favorable exchange rate policy are implemented as means for rationalizing national budget. Moreover, African states removed subsidies and adopted reforms on prices and foreign exchange of their currencies. Liberalization, internally and externally, and privatization were part of the package. Cost-sharing for government supplied services and restructuring of institutions have been required since then (Egulu, 2001; 19).

\section{2) Political Aspects}

The influence of forces of economic globalization have been giving hands to Western powers and institutions penetration into African states politics. The bipolar cold war order, in limited ways, enabled African young states to enjoy autonomy for some time, at least, by shifting alliance in between the two blocks, or by joining the non-alignment movement [G-77]. Following the end of the cold war, however, the unrestricted domestic sovereignty was override through the instrumentality of political conditionality. Since then most African states autonomy become 'a nominal'. In this regard, Mkandawire (2005) conceived that the failure of SAPs made World Bank to believe and recommend that there is no any way Africa to develop only through economic reform thereby pointed out for a new political reform which is more subtle and institutional.

The lack of economic development and political problems were viewed as significant factors that are closely linked each other. There were such rationales by the Breton Woods Institutions to their political reform policy prescription; Africa's economic development was "a crisis of governance... [and] the failure of public institutions [is] 'a root cause of Africa's weak economic performance: The quality of government has deteriorated with bureaucratic obstruction, pervasive rent seeking, weak judicial system, arbitrary-decision making" (Nabudere, 2000; 36).

On the basis of such an account these global financial institutions have also imposed political conditionalities to which African government are required to adopt. The presumed economic benefits as correlates to adoption of political reform include; maximum positive economic gains out of international trade, increasing foreign direct investment inflows, foreign aid, loans, and economic assistances. Accordingly, along with the above stated economic reforms, African states were obliged to adopt political pluralism, multi party system, and good governance, human and democratic rights, rule of law, freedom of the press and the media and civil associations and among others. In the view of BWIs, the adoption of neoliberal democracy based political reforms as a necessary condition for accruing the positive return of economic globalization; rapid economic growth, industrialization, poverty reduction, employment creation, and human development progress. Moreover, it promotes democratic transition or democratization; institutionalizes democracy, rule of law, and good governance; promotes peace via peaceful coexistence; and maximizes human security.

Contrary to these Daniel Nabudere (2000;37) the SAPs as a "political theory of adjustment," as nothing but one "intended to reinforce authoritarianism in Africa" (ibid; 38). Thanika Mkandawire concurs with Nabudere. Mkandawire explain that occasionally international institutions admit the influence they have over the policies African states adopted and pursued. He found that "Most policies that are today attributed to neo-patrimonialism and rent seeking were the orthodoxy of the day brought to Africa in well-funded and well-manned packages. The lack of "policy-ownership" is not a new thing in Africa and, alas, not a thing of the past either." (2001; 304).

\section{B. Prospects of Globalization and the Fragile Grounds of Africa: A Deadly Mix?}

Here, the marginalization of Africa's political economy from the global political economy of the global market capitalism is not a new phenomenon; Issues out of the past political and economic developments as a result of colonialism and its legacies, neo-colonialism and the cold war on the one hand; Internal limitations of African states, such as the following poor/fragile grounds are vital to be mentioned in hindering globalization from bearing fruits or forming deadly mix with aspects of globalization that has a devastating implications and impacts on the contemporary political economy Africa in general and most African states. Put simply, the following political and economic factors are attributable to the current marginalization of Africa and have made globalization not to have positive benefits. It should be underlined that this paper does not deny some of the positive returns of globalization on the political economy of African states. Rather it seeks to challenge the continued Panglossian view many westerners and even African fixated with much optimism without persistently evaluating changes appeared on policy levels, alignment and realignments of actors, proliferations of institutions, and theories.

Trying to generalize too much about the political economy nature, dynamics and issues of the 55 states of Africa is a herculean task at best if not an ontological impossibility. Equally, employing the dominant and general political economy features of Africa to each 55 states commits the fallacy of division. The discussion in the forthcoming sections shall proceed against the backdrop of these points. The obviously undeniable commonality of almost all African states is they are economically poor both in absolute terms and when compared with the rest world. Indeed, most African states lack political stability and democracy for long due to domestic and external factors. On the other hand, there is differences among them culturally, resources endowments, economic capacities, human capital, history, social stabilities, mode of production, and political systems and institutions, among other things. 
According to Samir Amin (1972; 28), “contemporary Africa can be divided into wide regions that are clear different from one another. But it is more difficult to analyze these differences -and to study their nature, origin, and effects -than to see them." Hence, the following discussion acknowledge as many inherent diversities as many crisscrossing and overlapping evolving convergence and divergence of issues, actors, institutions, and processes in the international political economy relations of African states hitherto. Without delving into uncovering the nature, origin, and effects of differences among African states, and underscoring the discernibility of the differences at international level not domestically, this study strives for discussing the deadly mix effects globalization have brought on the political economy of African states in the forthcoming sections.

\subsubsection{Weak Bargaining Power}

Obviously, the small physical size of a country which is attributable to the 'balkanization of the continent's various resource endowments due to colonialism and links with the earlier colonialists in the aftermath years of independence has in effect made most African states to be "too small, have too narrow resource bases, lack adequate capital and technical expert" (Cohen, 1982; 95).

Obviously, for many small African countries the situation of globalization has weakened their relationships with the developed western state. Most African countries have limited markets, shortage of skilled man powers, and scarce physical resources. Hence, it is no wonder to see the declining bargaining power of most African countries in the post-cold war era. The ever mounting amounts of foreign loan despite the continued deterioration of their terms of trade and declining inflows of FDI added with the expanding muscles of western countries, institutions and their INGOs into the politically higher areas of most states can sufficiently exposes the continued detrimental effects of the process of globalization and relations with Western powers. It still begs the neutrality of WB, IMF and WTO as forces of globalization meant to pave the way and manage IPE, and to complement the economic development and democratization prospect of developing countries, in deed. In the political sphere, the most important consequence is the erosion of sovereignty, especially on economic and financial matters, as a result of the imposition of models, strategies and policies of development on African countries by the IMF, the WB and WTO.

In the final analysis the political status of most African states has, to a larger extent, become subservient to the aforementioned globalist force. Indeed, what Nwake (2000) argued twenty years before still hold true to these days. He succinctly noted that most African countries are;

... now seem to have lost control of the policy making process, and are under pressure to accept dictation from creditor nations and financial institutions. . . . tend to discuss development issues less with their own nationals, and more with donors and creditors, about debt repayment, debt relief and rescheduling, and paradoxically about more development assistance (which rather than develop them further their underdevelopment and dependent (Nwaka, 2000:31).

As can be inferred from the above quote even a layman can distinguish the mismatch between neoliberal based economic and political reforms and what have prevailed overtly empirically. It confirmed how a policy prescribed for economic growth/development and democratization ends up being antithetical to both.

\subsubsection{Expansion of Informal Market-Distortion}

The expansion of the informal economy has developed alongside conventional sectors of the economy as a kind of negative image of the modern sector. Globalization has resulted in the economic reforms pursued by governments in the region in a bid to cope with foreign debt and budget deficits. These have included measures designed to restructure public expenditure, cut government subsidies to public companies and privatize state-owned companies. This has had led to a catastrophic impact on the economy and prompted a dramatic cut in the number of wage-earning jobs in both the public and private sectors (Delvaux, 2001; 13; Sandbrook, Richard, 1996;5).

Thus, forming a deadly mix, globalization has produced a massive unemployed labor that had no option than joining the informal sector that has long been a tradition in African countries and there by expanding it considerably in sub-Saharan Africa in the last decades. (Sandbrook, Richard, 1996; 5). Despite the shortage of reliable statistical data, it is estimated that the informal economy absorbs around 60 per cent of urban labor in sub-Saharan Africa. Accordingly, 93 per cent of the urban jobs created during the current decade will be in the informal economy. But the process of globalization, in its current form, seems unlikely to provide opportunities for turning this trend around (Ibid; 23).

In fact, the adoption of free market economy through prescriptions linked with stringent conditionalities by African countries with poor infrastructures, weak if not dysfunctional institutional set ups, and staggering legal regime negates the neoliberal development paradigm underpinning market mechanisms as a cause for an accelerated economic growth/development. In effect, the process of economic globalization has been putting on pressures for African countries to liberalize, privatization and deregulate their economy. Against the belief of western institutions regarding the positive benefits of adopting free market strategy for Africa's economy, the effects of avoiding measures aimed at protecting the infant industry via protection from competition with foreign firms and state-supported monopolies on vital areas on the one hand, and halting the provision of inputs and credit subsidies and/or undervalued foreign exchange to its fragile private sector has caused problems in many countries. Among other things, the already infant and weak private sector has gone from worse to the worst state in its performance, at best, it caused deindustrialization. (Sandbrook, Richard, 1996; 5).

Industrial policy plays an important role in stabilizing 
neopatrimonialism as it creates political space for politicians and bureaucrats to allocate government resources to specific groups of beneficiaries. These can be employed to strengthen ties of loyalty between individual politicians or bureaucrats and private beneficiaries, but also to buy political support from specific social and ethnic groups that are considered important for the survival of the incumbent regime... Consequently, politicians and bureaucrats who want to employ industrial policy for patronage and clientelism can easily find technical justifications to mask their political objectives (Altenburg,' 2011: 8).

\subsubsection{Opportunities to Labor and Resources intensive MNCs in Exploiting African Labor}

The effects of distortion of the market mechanism and the expansion of informal economy have been causing rampant unemployed force within the informal market. The parastatal institutions weakened the emergence and development of the private economy sector.

Despite the continued rhetoric on the likelihood positive effect of economic globalization in promoting industrialization with an increase inflow of FDI into Africa, neither the prevalence of abundant natural resources nor huge market size have never been quite appealing. The FDI policies of most African countries disregarded the above mentioned factors in their call for FDI inflows from developed Western countries. Indeed, even the small scale FDI inflow coming to the continent are known for their lack of the state of art technology besides the increasing pressure put on them to offer an incentive in order to attract investments. Tariff exemption and export subsidy the provision of cheap labor have been taken as an incentive as is the case in Africa's export processing zones (EPZs). In the end, the beneficiaries have been foreign investors, further compromising African countries' national sovereignty and the welfare of the labor force (Valasco, 2002; VI).

\subsubsection{Degeneration of Living Standard}

The above discussed deterioration of employment is likely to weaken productivity and tragically increase the wage gap between the formal and informal sectors. As Richard Sandbrook $(1996 ; 2)$ argued that the implementation of economic reforms by African countries were not without pitfalls. Examining relationship between trade openness and poverty reduction, Le Goff, Maëlan and Raju Jan Singh (2013; 2) find that "...with almost 50 percent of the population living below US\$1.25 a day, sub-Saharan Africa remains the poorest continent in the world. The large gains expected from opening up to international economic forces have, to date, not been realized in many African countries, especially for poor people. It seems that countries are not equally able to make use of the opportunities arising out of increased access to international markets."

As a condition for receiving loans governments were required to cut jobs, that is, to directly promoting unemployment in the continent the majority of its people are unemployed due to the infant development of its private sector, the inability of governments to provide jobs to white-collars let alone to the blue-collar, and the lack of domestic revenue to stirrup investment. Sandbrook (1996; 2) criticized some African countries that had "instituted agreed conditions, but then neutralized the effect of these reforms through countervailing measures (for example by freezing the salaries of civil servants, but then re-designating many civil servants to higher paid categories)".

Moreover, precarious employment, unfavorable working conditions, the lack of and ignorance about social welfare and health care measures, and the absence of any collective organization of labor are all factors which are blocking the growth and competitiveness of the informal economy and could encourage the continued survival of abuses and discriminatory policies targeting workers in this sector. While the number of poor people in the developing world decreased by 59 million from what it was in 1987. Making the total number of poor people in the developing world by 1998 to be 1,120 million. The number of poor people has increased from 217 million in 1987 to 291 million in 1998 in sub-Saharan Africa (World Bank, 2001; 17-23). More still, the proportion of population with less than one dollar a day increased from $55.8 \%$ in $1965-1969$ to $64.9 \%$ in 1995-1999 in least developed countries of Africa (UNCTAD, 2002).

\subsubsection{Africa's Affliction in Brain- Drain but labor Immobility}

This has, in turn, accentuated poverty and economic inequality as well as the ability of the vast number of Africans to participate meaningfully in the social and political life of their countries. Economic and social stagnation has also triggered a substantial brain- drain from Africa; further weakening the ability of African countries to manage their economies efficiently and effectively (Mkandawire, 2001; 307; Van De Walle, 1996; 249).

The developed western donor states and their institutions such as the WB and IMF have endorsed civil services reform programs through the SAPs and since 1980s, "a succession of fiscal stabilization programs has reduced government employment ...to the lowest level of any developing region" (Mkandawire, 2001;307). Its effect in causing brain drain to a limited extent and widespread migration of the blue collar to a large extent is undeniable. Brain drain does not apply to low and semi-skilled labor migrants.

The challenging aspects of globalization is, indeed, while it encourages and lends legal protections to the brain drain and "exodus [of] the continent's most talented minds"(Van De Walle,1996; 249), particularly "in sectors that are critically short of human resources such as the health and education sectors" (Mehari, 2008; 42), it neither offers conducive condition to the most affected unskilled and semi-skilled labor forces.

The problem of brain drain is a serious concern for Africa. As such, it is argued that "even if the data is still inadequate, the World Bank estimates 70,000 skilled Africans migration to EU and USA each year" (Ibid; 40). Other than the push and pull factors to the scenario the current globalization in its need for establishing a knowledge-based economy has caused the USA and EU hungry of Africa's skilled and professional class as can be understandable from the USA's Green Card and the EU's Blue Card under legislation (ibid). 


\subsubsection{Economic Recession: Trade, FDI, and Aid}

It is important to recap that African countries have limited exportable products as they are mainly producers of primary commodities that are particularly vulnerable to large price sways. Thus, the focus on open market policies in the era of globalization has not produced many positive returns to African countries primary goods for which demands and prices are externally determined (Egulu, 2001; 19).
As Le Goff, Maëlan and Raju Jan Singh $(2013 ; 1)$ note, "African countries have realized significant improvements in trade liberalization in recent decades, yet Africa remains the poorest continent in the world. It seems that the large gains expected from opening up to international economic forces have been limited in Africa, especially for poor people."
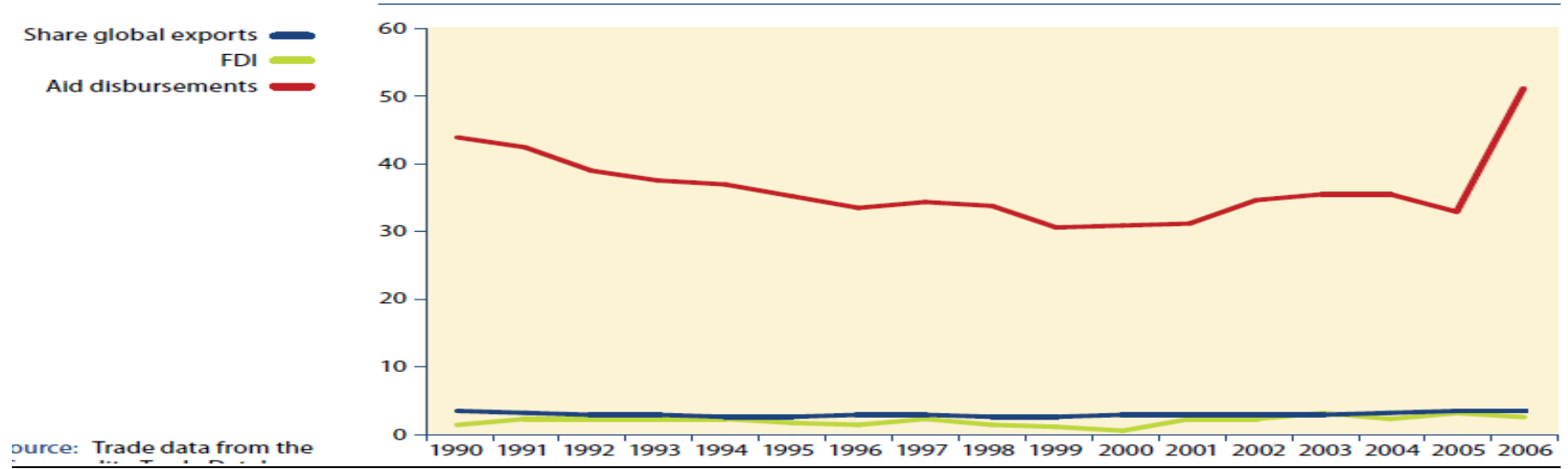

Figure 1: Africa's share of global exports, incoming foreign direct investment and as a recipient of aid disbursements, 1990-2006, in percentage.

Source: UN, $(2010 ; 6)$.

As can be inferred from the above figure, the economic marginalization of Africa since the advent of economic globalization overtly is clear. The data analyzed by UN's Office of the Special Adviser on Africa [2010] found the share of Africa's global exports to and the incoming FDI from

Figure 1. Share in Global Trade by Region, 1960-2011

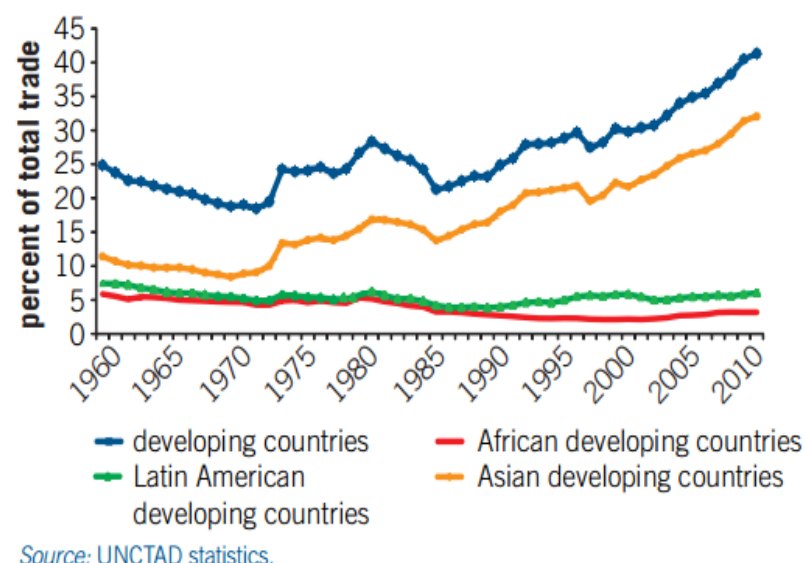

the world as small showing little change over 17 years; from 1990 to 2006. Africa's share of global exports and incoming FDI is small and has changed little since 1990. Yet, its share of incoming aid has been ranging between 30 to over $50 \%$ in the mentioned years. Indeed, aid inflows to Africa had been declining since 1990 until it start to grow since 2001.

Figure 2. Trade Openness by Region, 1980-2011

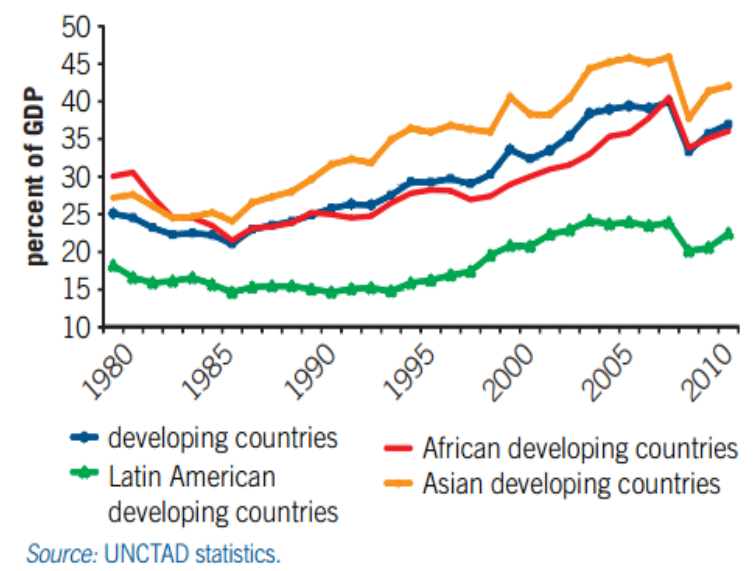

Figure 2: Comparative Share of regions in Global Trade (1960-2011) vis-à-vis Trade Openness (1980-2011) in \%.

Source: Le Goff, Maëlan and Raju Jan Singh (2013; 1).

The above figures explains the relationship between share in global trade by region as percent of total trade (1960-2011) and trade openness by region as per percent of GDP of regions (1980-2011) respectively. The share of Africa in global trade has been below $5 \%$. The total global trade share of Asian, Latin America, and Africa countries have been declining from the 1960 to 1970 s, though the starting point is different; and Latin America and African countries contribution to the total global trade have been declining while Asian developing countries have been witnessing improvements since the late 1970s (see Figure 1). Moreover, trade liberalization have been so large in Africa relative to
Asian countries in the 1980 s but larger relative to Latin American countries, the total share of Africa to the global trade have been by far low and declining (Figure 2).

The European Union is the major destiny of Africa's export trade followed by USA. Oil, natural gas, mineral resources, textile, apparels, and other manufacturing items constituted the major export items of Africa to USA for AGOA provided preferential market access. Similarly, though it is small China's reengagement with Africa has been raising the export share of Africa and the above stated items.

This had led many countries into the debt trap, with debts 
continuing to soak up the major portion of the least developed African countries budget. At the end the external debt stocks have deterred investment, encouraged capital flight and seriously undermined economic growth and unemployment (Mkandawire, 2005; 157). To sum up globalization has reinforced marginalization of African countries. Sundaram, et al (2011) note that since the early 1980s there have been remarkable impact of globalization on sub-Saharan Africa. Indeed, they provide a very conclusive fact and argued that,

The large gains expected from opening up to international economic forces have, to date, been limited, and there have been significant adverse consequences. Foreign direct investment in SSA has been largely confined to resource-especially mineral-extraction, even as continuing capital flight has reduced financial resources available for productive investments. Premature trade liberalization has further undermined prospects for the economic development of SSA as productive capacities in many sectors are not sufficiently competitive to take advantage of any improvements in market access. "(pp.1).

Despite the much exaggeration on the benefits expected from economic globalization in bringing about continued inflow of FDI based on the increased FDI in sub-Saharan Africa since the late 1990s, views about the marginal role of FDI in improving the political economy of African countries is getting weight particularly currently. According to UNCTAD (2005) expecting sustained and broad-based economic growth from FDI inflows into Africa lack empirical evidence, nor the strong remark on the employment creation potentiality of FDI is sustainable. The rush of many foreign investors into the mining sector of African countries' economies amply attest this fact. FDI in mining sector provides limited opportunity for employment creation, nor guarantees the diversification of exports or ensures a meaningful transfer of technology (Sundaram, Jomo Kwame, Schwank, Oliver and Rudiger von Arnim; 2011; 9-10). Sch

\begin{tabular}{|l|l|l|l|c|}
\hline & $1970-1979$ & $1980-1989$ & $1990-199$ & $2000-2008$ \\
\hline Share of World FDI & & & 9 & \\
\hline Developed economies & & 75 & 68 & 67 \\
\hline Developing economies & 75 & 25 & 31 & 30 \\
\hline Developing economies: Africa & 25 & 3 & 2 & 3 \\
\hline Developing economies: America & 5 & 8 & 10 & 9 \\
\hline Developing economies: Asia & 12 & 14 & 19 & 18 \\
\hline China & 8 & 2 & 8 & 6 \\
\hline Economies in transition & n.a & 0 & & 3 \\
\hline Share of developing country FDI & n.a & & 6 & \\
\hline Developing economies: Africa & & 10 & 31 & 11 \\
\hline Developing economies: America & 21 & 33 & 62 & 28 \\
\hline Developing economies: Asia & 47 & 56 & 25 & 61 \\
\hline China & 31 & 7 & & 21 \\
\hline Sourc: & n.a & & \\
\hline
\end{tabular}

Source: Sundaram, Jomo Kwame, Schwank, Oliver and Rudiger von Arnim $(2011 ; 10)$.

\subsubsection{Stagnating Patterns of Endogenous Social Development \\ and authoritarian (Mkandawire,2001;308). \\ states/government"}

The effects of globalization in terms of eroding sovereignty of states is known. It is more noteworthy in African countries. Notwithstanding to the legacies of the destructive effects of slave trade, colonialism, and neocolonialism on the inherent culture, social systems and institutions, contemporary process of globalization is seriously jeopardizing African socio-cultural values, beliefs, norms, systems and institutions which could rather have been instrumental to the institutionalization of democracy and internally derived economic progress (Nabudere, 2000, 11-55).

The imposition by BWIs of development strategies and prescription of political reforms on African countries has blindly overrode the importance of sociocultural establishments in hampering and/or facilitating the desired results. Indeed, the imposition of liberal democracy has institutionalized neither liberalism nor democracy in the new and young states of Africa. This is because "while the need for curbing authoritarian states and governments is understandable, the incapacitation of the state has been extended to democratically elected ones largely because the anti-state ideology rarely distinguishes between democratic

Thus, taking into account the imposition of the liberal democracy, it is clear that the underlying and fundamental principles of democracy on experiments in Africa was apparent at best, if not it is a deliberate undertaking aimed at thwarting the development/evolution of African based democracy fitting with the embedded and empirical socio-cultural systems and institutions of African countries. The prescription of neoliberal democracy as a one size fit all remedy for African countries whose particular historical, political, social and cultural realities is different from western developed countries and with each other is both Eurocentric and Afro-pessimistic (Andrzejewski, 1981).

For instance, the possibility of institutionalizing African specific democracy can be uncovered if one evaluates genuinely political dynamics in the "Regional State of Puntland" and "the self-declared 'Republic of Somaliland' that have emerged as semi-independent structures since the collapse of the Somalia republic in 1990s. Unlike the southern part of Somalia that have been raged by war and the periodic fighting happening between the armed forces of 
these entities over borders, the establishment of functioning governments and maintenance of higher levels of security in the northern parts of Somalia is what negates the viability of state in Africa if founded based on western developed countries political ontology of statehood and government.(The Life and Peace Institute and The Nordic Africa Institute and ABF Stockholm, 2007; 4).

Here, the embedded sociocultural setup, systems, and institutions, which is dubbed as traditional and primordial in pejorative sense, has not constrained these "states" and clans from maintaining statehood and government status for themselves despite the overt dismissive stance of members of the international community to proffer recognition hitherto. It is argued that "Changing the conceptual focus from failing state to nascent state-system enables a political shift from 'state-building' to 'systems-building'. The shift to systems-building develop strategies to support the consolidation and viability of Puntland into a viable entity like Somaliland. Here, the integration of traditional institutions and leaders into Puntland's institutional structure is called for and the international community is requested to direct its support towards clan elders and other community elders (Haldén, Peter, 2008;7).

The universalizing and homogenizing towards western oriented political and sociocultural values, beliefs, norms, systems and institutions effects of contemporary era of globalization have been downgrading, and hardly trying to obliterate African specific sociocultural fundaments. The distinct role these can play in complementing democratization with specific institutions, forms and processes without negating the particular historical, social and cultural realities of African countries is undeniable (Conference Paper,2001;18). Seen from the cultural nationalism perspective the application of Western democratic institutions on post-colonial African states without due regard on precolonial institutions and traditions, have been the most inappropriate models for a revitalized politics in Africa (Healey, John, and Mark Robinson' 1994; 127).

What has become common now a days, despite the need of African, is the connection between democratization and the real lives of the African people "as the exercise of power is reconfigured to satisfy minimal international requirements of periodic elections. . . . [in deed] Electoralism has come to consume democratic efforts to the detriment of broader and more systematic transformations" (Joseph, 2003; 160).

Indeed, the post colonial states of Africa were designed as inheritance reflecting colonial interests. Colonial socio-political institutions, systems, and laws continued as legitimate without adding excluded socio-political values, systems, institutions and interests of the endogenous population following independence. Hence, post-colonial states discouraged alternative pre colonial or endogenous African ways of organization at least by law. African states that joined the club of statehood after much struggle had, in a limited way, stultified endogenous social institution, development, and forces pertinent to the progress of Africa.
As a result, it has become strange to see a genuine and meaningful participation of people of Africa in the social and political life of their countries actively.

Also in respect to stifling endogenous social development it important to mention that advancement in technology and information in the ear of globalization had brought cultural invasion from outside that had made African states rapidly losing and further changing their already deteriorating endogenous cultures and ways of life to meet needs and tests required by the global production and supply forces.

In effect, the scientific and technological forces unleashed by globalization have facilitated Africans access to technology and information and having a positive effect. Yet, this has not been without expediency. Notwithstanding to the continued dependency on technology, this has been "stultifying the indigenous development of technology and distorting patterns of production" (ECA, 2001; 6). What else can be the direct effect of employing capital and technology intensive methods of production in a continent where there is an abundant labour calling for labour intensive production except for increasing unemployment and poverty (Ibid).

\subsubsection{Neo-patrimonialism: A Counterproductive Synthesis}

The economic policies and strategies of most African states are not designed based on economic rationality but based on political considerations. It is argued that "In Africa political institutions have on the whole evolved within neo patrimonial rather than corporatist regimes" (Nicolas Van De Welle, 1996; 457). Some western scholars and Medias have gone to the extent of attributing the level of poverty and the apparent incapability of achieving economic development of African countries to internal cultural factors. Noting the difficulty of imposing such question for political correctness, Clapham (1996; 820), argued that "Given the historical experience especially of peoples of African origin, it was understandable that any supposed explanation of their level of economic development in terms of their culture should be regarded as deeply offensive."

As it is known most of the first-generation leaders of Africa and development strategy was statist, or command economy, and even those who adopted a market-based capitalist economic strategy have interfered into the working of the economy. While Mkandawire (2001) viewed it optimistically as he dubbed first-generation leaders of Africa as developmentalist, Claude Ake $(1976 ; 1)$ categorized those statists leaders' intervention in the market pessimistically. Ake criticized these leaders for using the economy of the state to enlarge their economic power/status and to consolidate their power and the means of coercion. As a result, state run enterprises-that some times are called Parastatals-were a means or avenues to redistribute the national wealth to the concerned social bases (the so-called middle classes) thereby being characterized by corruption, nepotism and patrimonialism.

Sandbrook $(1996 ; 2)$ ascribed the prevalence of neopatrimonialism as the explanatory values of African countries to the influence of Western countries and their institutions deep interest of creating the political, social, and 
economic "conditions for capitalist expansion" since the 1990s. In this regard, much attention has been given to strengthen "the civil associations of classes and groups attuned to market-based reform, attenuating the costs to powerful interests that might sabotage the recovery programmes and identifying new political coalitions of beneficiaries to fortify beleaguered regimes." Hence, neopatrimonialism become the vital practice linking democratization with the creation of political and social conditions conducive for economic globalization. Political reforms African states are prescribed to adopt based on the policy tenets of neoliberalism include liberal democracy, social pluralism and market orientation. In effect, economic globalization thwarted both economic growth and democratization.

Because neoliberal based political reform tolerate authoritarian governments who advance the pace of western modernization even by using force upon their societies whom they identified as traditional and resistant, as the history of African countries of the 1960 s to 1980 s confirmed. Contrary to these, since the 1990s the sole criteria for ensuring external legitimacy and institutionalization of democracy has become whether one is statist or not, not if one becomes authoritarian or democratic. Thus, "political democracy would not follow but accompany, and indeed facilitate, economic and social modernization." (Sandbrook, Richard, 1996; 2).

In effect such state-run parastatals enjoyed the monopoly of the available thin market bottlenecking the emergency of the prerequisites structures and forces for a well functioning private sector economy in most African states. As such, Parastatals have weakened Africa's emerging national bourgeoisie by the very practice of "state ownership, overregulation, and official corruption" (Bratton and Nicolas Van De Welle, 1996; 457). For instance, in this respect it crucial to mention that the above highlighted post independence African middle class lacks the necessary entrepreneurship and technical skills as engines of market led development unlike their counterpart in Europe (Cohen, 1982; Ake, 1976).

Likewise, due to neopatrimonialism and clientelism that had persisted and the state's continued repression undermining actively capitalist form of accumulation have been insignificant. It is argued that added with clientelism "property rights are imperfectly respected and thee are powerful disincentives against private entrepreneurship and long-term productive investments" (Braton and Van De Walle, 1994; 467). On the basis of the above background globalization tried to impose the ideals of free trade in a situation where there is no the appropriate social agents and underling structure for it in the Post independent African states particularly in the post cold war era. Thus, the dominance of the ideals of open market and free trade coinciding with the era of globalization in Africa had no contribution to the increasing productivity as per the rhetoric goes on.

In fact, the issue of corruption and neo-patrimonialism have been the predominant defining feature most, if not all, states as rulers since independence have been assuming the state apparatus as a private domain and it was and is the persistence of these "amoral familism" (Osaghae,1995;67), or ,prebendalism which is partly be attributable to the current African predicament. It is stated that Africa's primordial and patrimonial relationship has impeded and weakened the state apparatus.

This, in turn, has been one of the factors deteriorating the state-society relationship. Hyden $(1983 ; 21)$ explained it in such an explicit way as it reads like that:

The economy of affection is an underestimated threat to the macro-economic ambitions of either capitalism or socialism in Africa. Derived from a mode of production in which the structural interdependence of the various production units is minimal or nil it has no provision from a systemic superstructure to keep it together. Instead the economy of affection is a myriad of invisible micro-economic networks, which, if allowed to penetrate society, gradually wear down the macro-economic structures, and eventually the whole system.

The ever-advancing integration of African countries into the global political economy under the dictates of neoliberal global order that reigned both political and economic reforms. Political reforms prescribing the institutionalization of electoral democracy, freedom of the press and media, Multipartism, and other values and principles of neoliberal democracy on the one hand, and economic reform based on free market strategy underpinned the liberalization, privatization, deregulation, and marketization of the economy to the forces of global political economy. What the political reform has been inducing is not the maximization of the economic benefits out of the logic of economic globalization; but quite the contrary-the promotion and protection of neopatrimonialism. As Robin Theobald (1994) confirms the growing integration of Africa into the global economy "further inflates the value of public office, as this opens the door to a type of ' gold-plated' patrimonialism in the form of opportunities for lucrative scams, bribes from transnational corporations, arms dealers, money launderers, and the like" (Theobald, 1994: 705).

\subsubsection{Exacerbating Conflicts in Africa}

In most African states inter-ethnic conflicts have been a common phenomenon since independence (Mazuri, 2008; 36-41; Bienen and Jeffrey Herbst, 1996, 27-8). More often than not, inter -states conflict and civil wars, on various causes, have been part of the political history of most African states both during the cold war era and thereafter (Zartman, 1996, 52). Of course, it is argued that "any African state can have boundary problems if it wants" (Zartman, 1969; 70) and the post cold war are no more different (Mclean, 2008; 16). The end of the cold war has made the external support to authoritarian, centralistic and one-party African states military and financial strength to slacken or liquidate.

Thus, this has led in case like Democratic Republic of Congo (DRC), Liberia, Sierra Leon, and Somalia to the failure of the state and disintegration of its monopoly control on means of violence. As a result, complex conflicts, loss of effective control on the territory and over the people as well as inability to provide appropriate security was apparent in some states of Africa such as DRC (Cater, 2005: 19-25) and 
Somalia (Grosse-Kettler, Sabrina, 2004; 14).

This had combined up with the structural transformation of African states towards the adoption of 'democratization' and other political reforms as enforced onto them by the Bretton woods institution's introduction of SAPs; thereby exacerbating and accelerating political tensions and internal conflicts on line to the previous existing ethnic or other kind of political grievances (Drame, 1996; 206-8; Zartman, 1996; 57-8).

In addition the unregulated and decentralized trade and finance of the era of globalization provides the chance to parties of the conflict (either the weak central government or the opposition sides) to engage in illicit trade and inappropriate exchange of locally available resources such as diamond and Coalton, highly demanded by modern technologies of the giant private multinational companies, at low prices (Cater, 2005:31-33 and Vallentine and Shearman, 2005:9) in resource abundant areas such as in DRC.

Even the explicit or implicit support of the forces of globalization on the sustenance of intra-states conflicts in areas known for poor resource endowments as in post-1991 Somalia has not been marginal. As Duffield (2000; 73-74) observes despite the lack of self-sufficient economy system the dictates of the logic of globalization has enabled formal and informal economic actors to establish successfully varied alternative networks. The absence of legal intra-and interstate economic transactions have promoted an illicit interaction of global economic actors and Somalian warlords. Indeed, the anarchy of commerce has not deterred an expanded illegal trade between warlords and foreign willing partners hitherto. It rather has strengthened the interdependence of war economies of Somalia with external funding. In view of Duffield globalization and liberalization have complemented the perpetuation of interclan conflicts and other forms of instability for "they have made it easier for warring parties to establish the parallel and transborder economic linkages necessary for survival" $(2000,74)$.

This in turn is making intra state conflict to be self perpetuating as permanent means of business (Ibid, 32 and Vallentine and Shearman, 2005:1). In return, the political economy of intra-and inter states war in the era of globalization have been further weakening African states political economy. For example, the now and then prevailing conflicts in most states of Africa even these days have been dwarfing the inflow of large size FDI into most states of Africa. Because, as noted by UNCTAD (2005), unlike other regions Africa provide a higher rate of return to FDI. Yet; many states of Africa are identified as ill-fated destinies for foreign investors due to the risk associated with overt or covert political instability or conflict (Sundaram, Jomo Kwame, Schwank, Oliver and Rudiger von Arnim; 2011; 9).

To sum up, as demonstrated above the end of cold war and the surge of globalization had a net effect of exacerbating and perpetuating intra state conflicts in Africa.

\section{AFRICA's POLICIES \& STRATEGIES TO COUNTER THE CHALLENGES OF GLOBALIZATION: LIMITATIONS \& DRAWBACKS}

\subsection{The Counter Strategies and Policies}

Given the fragility and weakness of their economies and politics which has resulted in the marginalization of the continent at large, African states have been making efforts to rectify this phenomenon in a cooperative way. The response to the marginalization of Africa in the global political economy mainly gives an emphasis on the establishment of regional and sub regional integrations on the one hand, and the acceptance and strengthening of cooperation with others emerging economies through a kind of South -South cooperation, particularly with BRICS states [that is, Brazil, Russia, India, China and South Africa]. Since then, consolidation of relations with China in the spirit of South-South Cooperation framework, as in the Bandung conference, have been advocated by many as an alternative to the Washington Consensus. Accordingly, the forthcoming section discusses these counter strategies briefly.

\subsubsection{Regional Cooperation and Integration (RCI) Schemes}

The limited capacity of African countries to tackle the challenges that economic globalization has been imposing upon their political economy have influenced these countries to establish various regional cooperation and integration schemes. There have been as many externally derived problems as internal limitations in trade, investment, security, infrastructure, and politics that have been affecting the wellbeing and security of African countries and their people since independence. One of the strategies African countries has chosen was the improvement of regional cooperation and regional integration to protect external challenges and to avoid internal pitfalls. Thus, RCI has long been high on the agenda of African countries, regions, and regional organizations since the early 1960s (Vanheukelom, Jan, Byiers, Bruce, Bilal, San and Sean Woolfrey, 2016; 1).

Cognizant of the fact that globalization have a negative impact on Africa, there have been attempts by African states to make maximum use of regional economic integration. The rationales are the need to "escape from economic isolation, to expand their markets by diversifying their economies and sustain export development by reversing deindustrialization" (Mwamadzingo, 2001; 8). In fact, there has been growing optimisms about the good effects of regional integration by African states.

It is viewed that regional integration will serve them as a means to gains from new trade opportunities, larger markets and increased competition which in turn leads to raise returns on investments, facilitate larger investments, and induce industries to relocate. Regional integration, of course, is often assumed that it "increase international bargaining power of states in the global market economy" (Adetula, 2008; 12) and it will enhance cooperation among member states and, at last, improve security. Likewise, it is argued that regional integration the efficiency, economies of scale, and it will 
provide experiences" (Mwamazingo, 2001; 7-8). An integrated market also provides a framework for African countries to cooperate in developing a common infrastructure - such as in financial services, transport and communications - and mechanisms for the joint exploitation of natural resources. The limited size of the market in most African countries means that African countries could greatly raise their growth prospects by increased intraregional trade (Conference Paper, 2001; 12).

In accordance with the aforementioned objectives and rationales of regional integration arrangement African states have entered the 21 st century being "restless for changes in the continental arrangements" (Mazuri, 2008; 44). One of the new developments that had called for a continental wide concern in the post-cold war was the transition of the OAU to the Africa Union (AU) as a respite from their "widespread disenchantment with the status quo" (ibid). The AU have then envisioned greater economic integration, the creation of a continental banking system, the establishment of a Pan-African parliament, and eventually a monetary union with one continental currency" (ibid;45). Under the aegis of AU various undertakings have been conducted so as to ameliorate the ever more marginalization of African countries from the global political economy.

There are about "30 regional trade arrangements (RTAs), most of which are part of deeper regional integration schemes... each African state belongs to four RTAs. ... There has been a renewed push in recent years to broaden and deepen RTAs in Africa" (Yang and Gupta, 2007; 399).

\subsubsection{South -South Cooperation: China}

In addition to sub-regional and regional cooperation and integration, African countries are recommended and have been persuading South-South cooperation since the late 1950s (Mujaju, 2000; 43). The historical roots of the South-South Cooperation go back to the 1955 Bandung Conference when not more than five countries were independent. Two decades later, in 1975, a UN Conference on South-South Cooperation was held in Buenos Aires. The underlying rationale was the importance of promoting solidarity and collective self-reliance through various cooperation agreements-Non-Alignment Movement- among developing countries. Specifically, it aims to contribute to economic and social development of developing countries, the transfer of technology and expertise knowledge among developing countries, the exchange of experiences in areas of mutual interest and benefit, to deal with the shared strategic challenges, and the strengthening and consolidation of bilateral relations (OECD, 2013; 10).

As Sanoussi Bilal notes, South-South cooperation is a development cooperation framework alternative to the dominant North-South relations (P.16) witnessing two basic dynamics. That is, it confirms not only the growing importance of the Southern economies and interaction with the world and among themselves but also the increasing importance of Southern initiatives vital for stimulating development. (Ibid; 3). There have been two typically underpinning pillars of these two dynamics. These are strengthening economic cooperation through trade and technology flows among developing countries and providing technical assistance by building the technical capacity of developing countries through training, exchange of expertise, and sharing of experiences and know-how (OECD, 2013; 4).

Indeed, south-south cooperation is a generic term. There have been various kinds of relations taking place within the south-south cooperation framework umbrella. Non-Alignment Movement, G-77, Emerging economies, and the BRICS. For the sake of clarity, this study shall deal with Africa-China relations within the South-South cooperation framework. Narrowing the discussion with China needs to be understood as a purposive selection for it signifies the rise of new hegemon and its engagement with Africa is inclusive of the majority of states. Besides its largest territorial size, economic power and population, China is one of the permanent members of the UN Security Council with a veto power. That is, it has a political power in international affairs (Bilal, Sanoussi, 2012; 15; I. Bergamaschi and A.B. Tickner, 2017; 6).

The first emerging economy country that come to Africa under the south-south cooperation framework spirit is China. By the time African countries economic plight is escalating since the early 2000s due to the effects of economic globalization, China appeared on the horizon. These relations open the door for the commencement of a China-Africa Cooperation Framework, named FOCAC/CACOF since 2000 to be held every three year in which about 47 African heads of government/state participated.

Table 2: Africa's trade with newly emerging economies, 1995-2006 (billions in dollars)

\begin{tabular}{|c|c|c|c|c|c|c|c|c|}
\hline & $\begin{array}{l}\text { Braz } \\
\text { il }\end{array}$ & a Chin & India & $a^{\text {Malaysi }}$ & $\begin{array}{ll} & \text { Russian } \\
& \text { Federatio } \\
\mathrm{n} & \end{array}$ & $\begin{array}{r}\text { Republi } \\
\text { c of Korea }\end{array}$ & $\begin{array}{l}\text { Turke } \\
\mathrm{y}\end{array}$ & $\begin{array}{l}\text { Total Emerging } \\
\text { countries }\end{array}$ \\
\hline \multicolumn{9}{|l|}{1995} \\
\hline Total Trade & -0.1 & -1.0 & 0.3 & -0.4 & 0.0 & -0.8 & 0.3 & -1.7 \\
\hline Non-oil & -1.1 & -1.3 & -0.5 & -0.4 & 0.0 & -1.8 & -0.7 & -5.7 \\
\hline \multicolumn{9}{|l|}{2000} \\
\hline Total Trade & 1.6 & 0.5 & -0.3 & -0.4 & -0.7 & -0.1 & 1.4 & 1.9 \\
\hline Non-oil & -0.8 & -3.1 & -0.5 & -0.4 & -0.6 & -2.2 & -0.1 & -7.7 \\
\hline \multicolumn{9}{|l|}{2006} \\
\hline Total Trade & 0.6 & 2.2 & 4.5 & -1.1 & -2.0 & -4.2 & 2.8 & 2.8 \\
\hline Non-oil & -5.9 & -18.8 & -3.0 & -1.1 & -1.0 & -7.2 & 1.9 & -35.1 \\
\hline
\end{tabular}

Source: Adopted from UN, $(2010 ; 7)$. 
Taking an eleven years of trade data, the UN [2010] study found that "In aggregate, Africa's trade with the newly emerging economies was in balance in 2006 , a similar picture to that which prevailed in 1990 and in 2000. If oil is excluded, then Africa's trade balance with the emerging economies is in deficit, with a major increase in this deficit between 1990 and 2006."

(Ibid).

$$
\begin{aligned}
& \text { ce: Calculated from } \\
& \text { in of Trade Statistics } \\
& \text { tabase, accessed via } \\
& \text { ESDS, March } 2009 .
\end{aligned}
$$

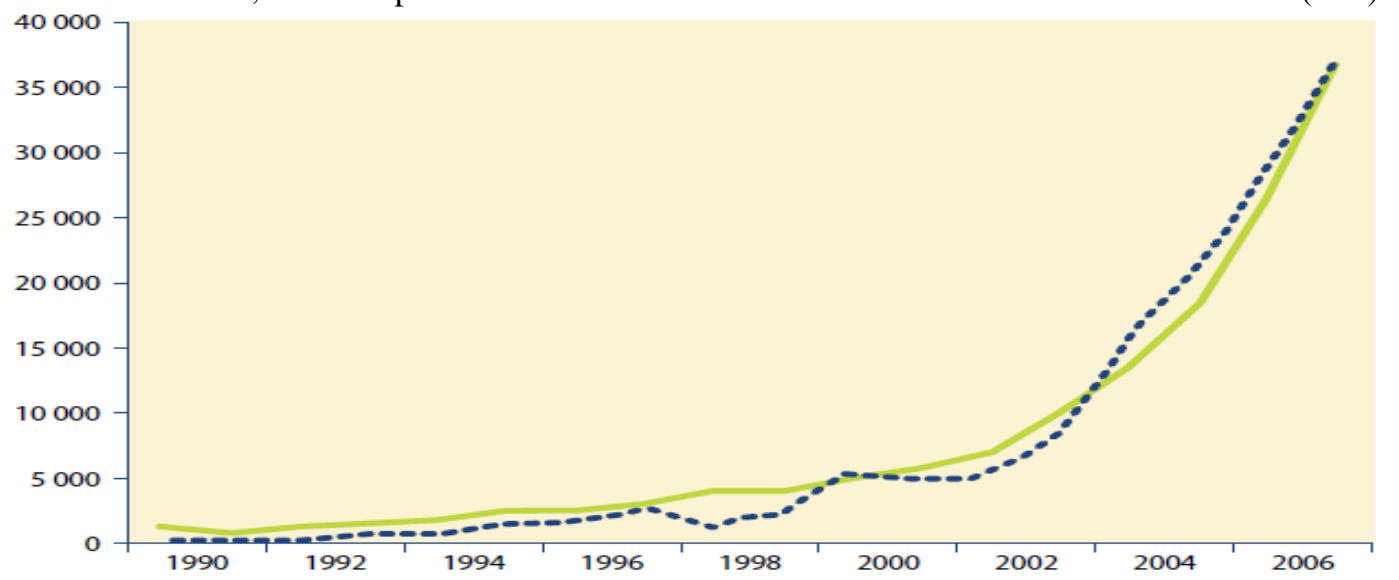

Source: Adopted from UN (2010; 46).

Figure 3: China's Trade with Africa, 1990-2007 in dollars

Indeed, at the $5^{\text {th }}$ FOCAC and the inauguration of the new African Union [AU] headquarter which China built with a \$ 200 million cost, as a gift for Africa, African leader had ascribed "the beginning of the African Renaissance," to the reemergence and commitments of China for a win-win partnership with Africa (Lyle J. Morris, Larry Hanauer, 2014; 26).

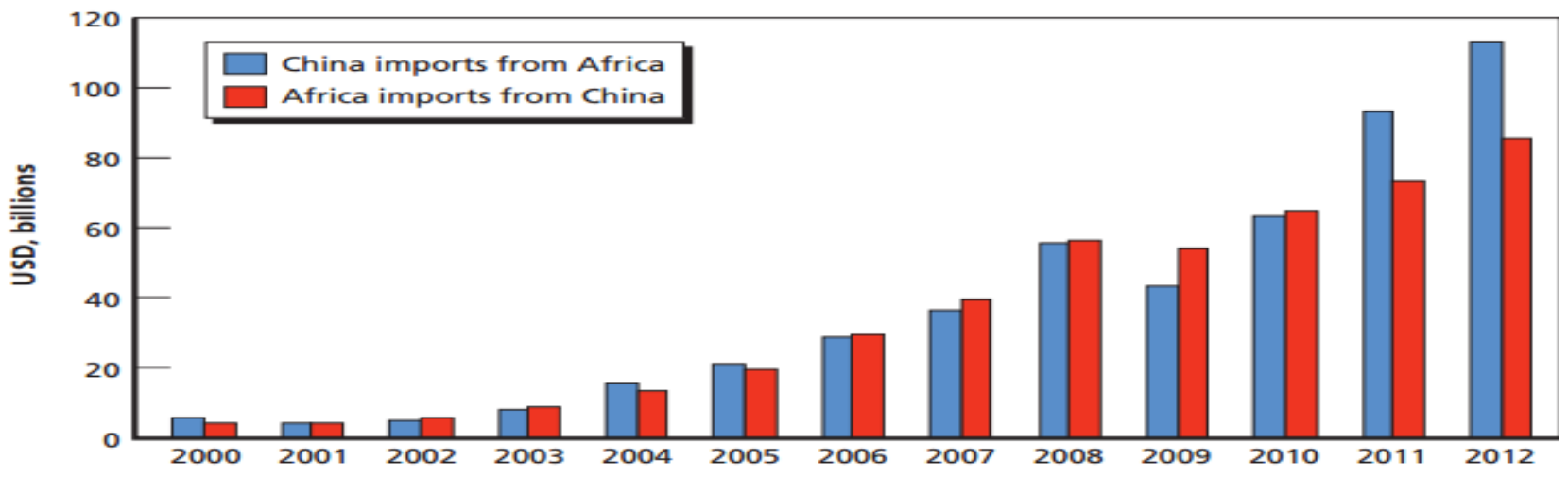

Figure 4: China-Africa Imports and Exports trade, 2000-2012 in billions dollars

Source: Lyle J. Morris, Larry Hanauer, [2014; 27$].$

Moreover, assessing the foreign development support of BRICS to developing southern countries reveals that China is the first country not only to start foreign assistance program in 1950 but also has provided an estimated absolute foreign assistance of 3.9 billion USD in 2010. Its assistance focuses on Africa and Asia predominantly. The sector focus of its foreign assistance includes infrastructure, industrial development, and energy resources development. (Bilal, Sanoussi, 2012; 25).

The contemporary China-Africa relations is said to have been going on under the South-South Cooperation framework. Many advantages are expected from such South-South co-operation with China by African states as a way out to their marginalization assuming that it will likely help them to "keep pace with the world's scientific and technological development, and thereby cope effectively with the challenges of the knowledge economy" (Shelton, 2007; $100)$, but expecting gross benefits or possibly mutual will be problematic.
What rather amount plausible, on the ground, is that:

[E]even if China continues to claim as a mutual friend sister or brother to African leaders' states, it is unlike to expect China to remain friendly ever. The more business it does as a great power in Africa; there it will make rather less credible the claim to be just another developing country that comes to Africa bearing only good will (Ellis, 2006:34).

Even its contemporary engagement in Africa is not sufficiently attractive and beneficial given the fact that "Chinese activity in Africa is in the hands of state-owned enterprises is hard to the advantage of African's masses because it considered and entrance corruption (the dominant 'political culture ' of most African leaders as has been stated in section two of this paper), low productivity and adverse welfare and working conditions for African labor that are the norm in most government owned banes in Africa (Hawkins, 2006:63).

"The South is dominated by the situation of emerging players, which are themselves largely dominated by China. In terms of the dynamics of developing countries, Asia is the 
lead pole, followed by Latin America and only then Africa." (Bilal, Sanoussi, 2012; 10). Yet, the rise of some southern countries into regional economic hegemony, the growing importance of South-South relations and the much optimism about it cannot guarantee African countries a stable and viable alternative global economic structure. There is uneven process between and within countries and the South is still confronted with poverty challenges, particularly most leading South-South Cooperation countries like China, Brazil, and India hosts the largest number of poor people (Ibid; 11; I. Bergamaschi and A.B. Tickner, 2017;9)

Needless to mention, the cooperation seems to have been established based on the common view both have of the global political economy system and their distinct strategic consideration. As such, China's focus on such cooperation is part of its stance and effort to oppose 'unilateral global dominance' and to build a stronger political relationship which will help support its diplomatic offensive against 'hegemonism' through African economic cooperation (Shelton, 2007;99).

\subsection{Limitations and Drawbacks of the Countering Policies and Strategies}

There are numerous problems which in effect have continued to impede the progress of regional integration in Africa; and the Sino-Africa cooperation as south-south cooperation has not yet come up with viable positive alternatives. Hence, some of the drawbacks and limitation of the marginalized African states counter strategies and policies are discussed in a brief manner.

\subsubsection{Regional Integration Schemes}

Africa's regional integrations schemes face enormous constraints and challenges at the crucial juncture of establishing the African Union. Some are due to ambitious goals relative to limited resources and capacities while some are due to lack of political will and strict deep adherence to national sovereignty. As has been witnessed there has been divergent interests of African states during the various stages that have led to the formation of the then AU in which ownership problem, i.e., there were a contest in hosting these regional institutions, had been one of the showcase for African countries political will and interest harmonization. The systemic problems that hamper the development of national economies also impede Africa's integration. Still, regional economic communities represent an important effort at breaking down colonial demarcations (ECA, 2001; 16).

As a synthesis it is argued that regional integration arrangements such as AU and NEPAD are closely linked to the objectives of the various regional arrangement comprises of, for example, SADC, ECOWAS, and IGAD. However; there is a problem of coordination between the continental/regional and the various sub-regional integration efforts; and it is argued that:

"[t] he future of the relationships between the AU and the sub-regional Organizations will depend, however, in no small measures upon the development of both the AU and the various sub-regional organizations themselves. This has several political ramifications, demanding complex institutions and structures, and extensive political wills, as well as unity of objectives, and commitments at national, sub-regional and continental levels (Adetula,2008;20).

Implementation has not been perfect, \& there have been periods of inaction $\&$ regressing. More important is whether regional economic communities can provide a basis for concrete progress and future growth. The enlarged community markets were expected to expand trade within regions, overcome the constraints of small markets, and prompts investments in larger industrial projects - especially manufacturing. That has not happened (ECA, 2001; 16).

Most African countries have identical production structures so that their exportable products become competitive rather than harmonizing. Transportation and communication facilities are not adequate; and there is no common currency so that problems at either continental or sub- regional level will likely be established. In addition to this, "the continued existence of tariff and non-tariff barriers, a fear of losing out to more developed member state(s) of sub regional groupings, and differences among political leaders have remained obstacles to closer integration throughout the continent" (Mwamadzingo, M, 2001; 7-11).

NEPAD is also a donor oriented given the fact it established "as a partnership between Africa and their major donors"(Mazuri,2008;45) so that its agenda to rectify depends upon the improvement in trade and market access, foreign aid provision and debt cancellation, capital flow through FDI flows (Loots, 2007; 18). This is so, most of these regional and sub -regional integration and cooperation schemes have not as yet been independent of the interests and influence of both internal and external actors and also has failed to deal with some of the problems which it has identified as triggering factor to the continents marginalization such as war, lack of democratization (Okoth, 2008; 22-37; Mazuri, 2008; 36 -50). More tellingly, it is stated that:

[e]Efforts by African countries to formulate economic development models, strategies and policies which, in their view, reflect better their situation, interests, goals and objectives, embodied in documents such as the Lagos Plan of Action, Africa's Priority Program for Economic Recovery and Development, and the Abuja Treaty creating the African Economic Community, have been all but abandoned (Conference paper, 2001;10).

Regional integration processes as viewed as an active dimension of south-south cooperation. For example, Bilal finds that they are facing innumerable hurdles often leading into disappointing results, particularly in Africa as in the case in Central and Southern America. Among other things, he underlines the difficulty of translating ambitious agenda into concrete actions. More importantly, divergent economic and political interests and covert or overt rivalries have been seriously jeopardizing progresses towards effective integration. The role regional integration processes have been playing in averting the negative side effects of forces of economic globalization have been for long marginal. Most 
regional integration processes in Africa underestimates the social and political dimensions that need to be evolved in juxtaposition with the integration processes. The difficulty of dealing with 'Summit mania' and "'regime boosting regionalism"" amply demonstrates the inherent socio-cultural and political bottlenecks. In fact, it has been customary practice to see heads of states/governments "going from Summit to Summit with no concrete deliverables and hence progress in regional integration initiatives"-Summit mania and observing some "heads of states seeking to boost their own standing and legitimacy through the regional framework, for domestic purposes, with no real concern for effective regional integration processes,"-"'regime-boosting regionalism."' (Bilal, Sanoussi, 2012; 28). On the other hand, the mismatch between regional commitments and national level of implementation have been poor at best, and contradictory at worst, and the role of regional hegemons have not been always encouraging. For example, Nigeria (as in ECOWAS) and South Africa (as in SADC) have been stimulating regional integration processes (Ibid). Yet, the positive role Egypt and Ethiopia can play in their own respective regions have been, to a limited scale, clouded by various factors.

\subsubsection{South-South Cooperation}

It is also becoming increasingly apparent that the African states who are members in the WTO are beginning to set their own agendas, which focus on opening markets to their exports and rebalancing past trade accords. They are becoming more vocal and determined both to become more active and to avoid repeating earlier mistakes. However, they were not articulative of their interests and have been repeatedly in a defensive than offensive mode (Jensen and Peter, 2007; 20-21).

The case was not merely attributable to whether China has advanced Africa's case in the international fora or not but on what basis and for whose interest and for how long? The ability of the South to shift thinking in the WTO to incorporate the interests of the developing countries rests on its ability to rally a united and enduring political front. The history of South-South economic co-operation is marked by failures to bring this about. However, the political and economic context within the WTO, as well as the broader international economic system is dynamic, and many factors in the calculations have changed considerably.

\section{CONCLUSION}

In the final analysis, it is important to wind up this sub topic by posing the question "Is it what Marxist and nationalists perspectives or liberalists argument about the nature and effects of the contemporary age of globalization marked by so called interdependence more accurate in explaining the above effect on Africa?" What rather would appear as plausible would be the Marxists and economic nationalist are better in explaining as the aforementioned discussion had affirmed.

Neither regional integration nor South-South Cooperation seems to have rescued Africa from the continued onslaught of globalization in every matter of the continent. In fact, Africa will indefinitely remain being marginalized and political democratization and economic decline will likely remain being unresolved as it has got attack from the domestic political climes of most African states which was determined to be limited merely on making annually façade and unfair periodic election for the sake of merely getting the favor of western states.

\section{REFERENCES}

[1] Ake, C. (1996) Democracy and Development in Africa, New York: Brookings Institution.

[2] Akindele, Gidado, and Olaopo, (2002)," Globalization, Its Implications and Consequences for Africa". Available @laopwale@yahoo.com

[3] Alden and Sidiropoulos, (2006), "China and Africa: Friendship and Revival in the New Century". UPDATED: December-15-2006 NO.44 NOV.2, 2006.

[4] Altenburg, T. (2011). Can Industrial Policy Work under Neopatrimonial Rule? Working Papers.

[5] Andreas, Peter (2004). "Illicit international political economy: the clandestine side of globalization" in Review of International Political Economy 11:3 August 2004: 641-652

[6] Andrew Hurrell and Ngaire Woods, (1995), 'Globalization and Inequality', Millenium 24:3 pp.447-470.

[7] Andrzejewski, B. W. (1981). "The survival of the national culture in Somalia during and after the colonial era," A Paper Presented to UNESCO Conference, Pp.108-118.

[8] Bergamaschi and A.B. Tickner, (2017; 1-27). "Introduction: South-South Cooperation Beyond the Myths-A Critical Analysis," in South-South Cooperation Beyond the Myths: Rising Donors, New Aid Practices? International Political Economy Series, Bergamaschi, Isaline, Moore, Phoebe, and Arlene B. Tickner, edi, Pp. 1-27.

[9] Bilal, Sanoussi, (2012), "What is the Rise of South-South Relations About? Development, not Aid," in European Center for Development Policy Management Paper No 70, Pp. 1-37.

[10] Boafo-Arthur, Kwame, [2000], "Trapped in Development Crisis and Balkanisation: Africa Versus Globalisation," In African Journal of Political Science / Revue Africaine de Science Politique, Vol. 5, No. 1 (June 2000), pp. 124-145. Published by: African Association of Political Science. Available at https://www.jstor.org/stable/23489907. Accessed: 04-04-2020.

[11] Busch, Marc and Eric Reinhardt (2004) "The WTO Dispute settlement mechanism and Developing Countries" available @ http://WWW.sida.se/publications

[12] Cater, Charles (2005). 'The Political Economy of Conflict and UN Intervention: Rethinking the Critical Cases of Africa.' In Vallentine, Karen and Sherman, Jake. eds. 2005. The Political Economy of Armed Conflicts: Beyond Greed and Grievance. Lynnerienner publishers, Inc, Boulder, USA.

[13] Chomsky, Noam (1997) "Market Democracy in a Neoliberal Order: Doctrrines and Reality" in Z magazine, pp.1-25.

[14] Clapham, Christopher (1993). "Democratization in Africa: Obstacles and Prospects" in Third World quarterly, 14(3), pp 423-438

[15] Conference Paper, (2002), "The Challenges of Globalization to Democratic Governance in Africa", Addis Ababa, Ethiopia, 2002.

[16] Dan Deudney and John Ikenberry, (1993), 'The Logic of the West', World Policy Journal 10: 17-29.

[17] Dani Rodrik, (1999), The New Global Economy and Developing Countries: Making Openness Work. Washington DC: Overseas Development Council.

[18] David Held, Anthony McGrew, David Goldblatt, and Jonathan Perraton, Global Transformations: Politics, Economics and Culture (Cambridge; Polity, 1999).

[19] Delvaux, Emile (2001). "The challenge of the informal economy," in "The Challenges of Globalization in Africa: The Trade Union Response," Valasco, Manuel Simon (2002) ed, Labor Education 2001/2, No.123.pp.1-56.ILO Bureau for Worker's Activities

[20] Duffield, Mark. 2000. Globalization, Transborder Trade, and War Economies. In: Mats Berdal and David M. Malone (eds.). Greed and grievance. Economic agendas in civil wars. pp. 69-89.

[21] Egulu, Lawrence (2001). "A new approach to adjustment," in "The Challenges of Globalization in 
[22] Africa: The Trade Union Response," Valasco, Manuel Simon (2002) ed, Labor Education 2001/2, No.123.pp.1-56.ILO Bureau for Worker's Activities

[23] Ehlermann and Lothar Ehring (2005). "Decision-making in the WTO: Is the consensus practice of the WTO adequate for making, revising and implementing rules on international trade?", in journal of international law 8(1),51-75.

[24] Fafowora, O.O. (1998). "Management Imperatives of Globalisation", Management in Nigeria: Journal of Nigerian Institute of Management Vol. 34, Nos. 2-4 April -December, pp. 5-9.

[25] geography perspectives in United Nations Conference on Trade and Development. Discussion Paper. No. 174.August.

[26] Grieco, M. And Holmes, L (1999) Tele Options for Community Business: an opportunity for economic growth in Africa" Africa Notes (October) pp 1-3.

[27] Grosse-Kettler, Sabrina, (2004), "External Actors in Stateless Somalia: A War Economy and its Promoters," in Bonn International Center for Conversion Paper 39, Bonn, Germany, Pp. 1-40.

[28] Haldén, Peter, [2008], "Somalia: Failed State or Nascent States-System?" FOI, Swedish Defence Research Agency Somalia Report Papers 1, Report no FOI-R--2598-SE, Stockholm, Pp. 1-65.

[29] Hawkins, Tony (2006). "Design or Desperation: Trade and Investment in Post-Mugabe Zimbabwe”. In African Analyst, Third quarter 2006, P. 60-68).

[30] Healey, John, and Mark Robinson, (1994). Democracy, Governance and Economic Policy: Sub-Saharan Africa in Comparative Perspective. London: Overseas Development Institute Development Policy Studies, Pp. 1-196.

[31] Jeffrey Herbst (2005). "Africa and the Challenge of Globalization". Provost, Miami University Presented at the Conference on Globalization and Economic Success: Policy Options for Africa, Singapore, 7-8 November 2005 pp.1-16

[32] Kindleberger, Charles (1986): "International public goods without International Government" American Economic Review, Vol. 76, No. 1, March.

[33] Lavussa, Bannadi (2005). "The new China" the new which in Africa and the world" in African Business December 205. No. 315

[34] Le Goff, Maëlan and Raju Jan Singh, (2013), "Can Trade Reduce Poverty in Africa?," in World Bank's Poverty Reduction and Economic Management (PREM) Network Economic Promise Number 114, Pp. Available at www.worldbank.org/economicpremise.

[35] Linard, André (2001). "The brain drains: Losing one's head," in "The Challenges of Globalization in Africa: The Trade Union Response," Valasco, Manuel Simon (2002) ed, Labor Education 2001/2, No.123.pp.1-56.ILO Bureau for Worker's Activities

[36] Lishan Adam (2004). "Information and Development in Ethiopia", in Ethiopian Economic Association, vol.7 No.3 December 2004, pp.16-31.

[37] Loots, Elsabe (2007). "NEPAD and the capital flows initiative: Can Africa walk the walk?", The African Economist,29(58), pp.18-23.

[38] Lyle J. Morris, Larry Hanauer, [2014], Chinese Engagement in Africa: Drivers, Reactions, and Implications for U.S. Policy, National Security Research Division. Washington, DC: Rand Corporation.

[39] Madunagu, E, (1999), "Globalisation and its victims", Guardian July 26; 53-68.

[40] Mannah, Shermain (2001). "The impact of globalization in Africa and the response of trade unions: The case of South Africa," in "The Challenges of Globalization in Africa: The Trade Union Response," Valasco, Manuel Simon (2002) ed, Labor Education 2001/2, No.123.pp.1-56.ILO Bureau for Worker's Activities

[41] Martel, Luke, (2002) available http://www.sussex.ac.uk./sociology/pofile1720.htm

[42] Mayer, J. (2004). Industrialization in developing countries: some evidence from new economic

[43] Mehari Taddele (2008). "Brain Drain and Its Adverse Impacts on the achievement of MDGs and Poverty Reduction" in The Eye on Ethiopia and the Horn of Africa, 27(153), 2008, pp.40-42

[44] Misser, François (2001). "Multi-speed globalization, democratization and conditionality" in "The Challenges of Globalization in Africa: The Trade Union Response," Valasco, Manuel Simon (2002) ed, Labor Education 2001/2, No.123.pp.1-56.ILO Bureau for Worker's Activities

[45] Mkandawire, Thandika (2001). "Thinking about developmental states in Africa", in Cambridge journal of Economics 2001, 25,289-313.

[46] Mkandawire, T (2005) "The Global Economic Context" in Towards A new Map of Africa, Wisner, etal, eds. United Kingdom and USA: Earthscan.
[47] Mkandawire, Thandika, (2013), "Neopatrimonialism and the political economy of Economic Performance in Africa: Critical Reflections," in Working Paper/Institute for Futures Studies, 2013:1; Pp. 1-62. Stockholm 2013.

[48] Monshipouri, M, etal (2003). Constructing Human Rights in the Age of Globalization. New Delhi: Prentice-Hall of India Private Limited

[49] Mwamadzingo, Mohammed (2001). "Regional integration in Africa: Getting it right", The Challenges of Globalization in Africa: The Trade Union Response, Valasco, Manuel Simon (2002) ed, Labor Education 2001/2, No.123.pp.1-56.ILO Bureau for Worker's Activities

[50] Ngaire Woods (1999), 'Good governance in international organizations', Global Governance 5 (1999) pp.39-61 at p.56.

[51] Nwaka, G. I. (2000) "Higher Education, the social sciences and National Development in Nigeria" The Nigerian Social Scientist, Asya: Social Science Academy of Nigeria, (March), Volume 3 No 1, pp $25-33$

[52] OECD, (2013), "Trade-related South-South Co-operation: China," On Policy Dialogue on Aid for Trade, COM/DCD/TAD (2012).

[53] Ohiorhenuan, J.F.E. 1998. "The South in an era of globalization", Cooperation South, No. 2, pp. 6-15.

[54] Ohuabunwa, Mazi S.I. (1999): The Challenges of Globalisation to the Nigerian Industrial Sector" Nigerian Tribune December 14, PP. 20 21.

[55] Osaghae, Eghosa E (1995). "Amoral Politics and Democratic Instability in Africa: A Theoretical Exploration" in Nordic Journal of African Studies 4(1):62-78

[56] Ouattara, Alassane, D (1997) "The Challenges of Globalization for Africa". Deputy Managing Director of the International Monetary Fund at the Southern Africa Economic Summit sponsored by the World Economic Forum, Harare, May 21, 1997

[57] Rijnierse, Elly (1993). "Democratisation in Sub-Saharan Africa? Literature Overview," in Third World quarterly, 14(3), pp 647-663

[58] Rugumamu, Séverine M. (2001) Globalization and Africa's Future: Towards Structural Stability, Integration and Sustainable Development.

[59] Sandbrook, Richard, (1996), "Democratization and the implementation of economic reform in Africa," in Journal of International Development: Vol. 8, No. 1, 2-20.

[60] Sandbrook, Richard, (1996), "Democratization and the implementation of economic reform in Africa," in Journal of International Development: Vol. 8, No. 1, 2-20.

[61] Sundaram, Jomo Kwame, Schwank, Oliver and Rudiger von Arnim, [2011], "Globalization and development in sub-Saharan Africa," in DESA Working Paper No. 102, ST/ESA/2011/DWP/102, February 2011; pp. 1-44

[62] Tandon, Y. (1998a). "Globalisation and Africa Options" (Part One) in AAPS Newsletter, Harare" African Association of Political Science, Vol. 3, No.1, January- April.

[63] Tandon, Y. (1998b). "Globalisation and Africa's Options" (Part two) AAPS NEWSLETTER, Harare, AAPS Volume 3, No. 2, May August.

[64] The Life and Peace Institute and The Nordic Africa Institute and ABF Stockholm, (2007). Somalia: A Nation Without A State.

[65] Theobald, R. (1994). Lancing the Swollen African State: Will It Alleviate the Problem of Corruption? The Journal of Modern African Studies, 32(4), 701-706.

[66] UN, (2010), “Africa's Cooperation with New and Emerging Development Partners: Options for Africa's Development”, Office of the Special Adviser on Africa, PP. 1-112.

[67] UNCTAD (2002). Economic Development in Africa: From Adjustment to Poverty Reduction: What is New? UNCTAD/GDS/AFRICA/2, United Nations Conference on Trade and Development, Geneva.

[68] UNCTAD (2005). Economic Development in Africa: Rethinking the Role of Foreign Direct Investment. United Nations Conference on Trade and Development, Geneva.

[69] Valasco, Manuel Simon (2002). "The Challenges of Globalization in Africa: The Trade Union Response," Labor Education 2001/2, No.123.pp.1-56.ILO Bureau for Worker's Activities.

[70] Vallentine, Karen and Sherman, Jake, (2005). The Political Economy of Armed Conflicts: Beyond Greed and Grievance eds. Lynnerienner publishers, Inc, Boulder, USA.

[71] Vanheukelom, Jan, Byiers, Bruce, Bilal, San and Sean Woolfrey, (2016), "The political economy of regional integration in Africa: What drives and constrains regional organisations?" AN ECDMP Synthesis Report, January 2016, Pp. 1-56. 
The Challenges of Globalization to Africa: Theoretical Reflections and Practical Assessments

[72] Wath, Kobus Vander and Dirk Kotze (2006). "Africa and China: A neglected opportunity", African Analyst. Third Quarter 2006, P. 43-59.

[73] Wiseman, J. (1993). "Democracy and he new political pluralism in Africa: Cause, Consequences and Significance," in Third World quarterly, 14(3), pp 439- 449

[74] Woods, Ngaire (2000). The Political Economy of Globalization. Basingstoke: Macmillan.

[75] World Bank (2001). Global Economic Prospects. World Bank, Washington, D. C 